\title{
Elewacje wentylowane - problemy wykonania i odbioru
}

\author{
Ołeksij Kopyłow \\ Zaktad Konstrukcji i Elementów Budowlanych, Instytut Techniki Budowlanej, \\ e-mail:o.kopylov@itb.pl
}

Streszczenie: W artykule, na podstawie doświadczenia badawczo-eksperckiego ITB, omówiono najczęściej spotykane pomyłki podczas wykonania i odbioru elewacji wentylowanych. Przytoczono błędy wynikające z niedoskonałości dokumentacji projektowej, niewłaściwego przygotowania wykonawców oraz kadry nadzorującej.

Słowa kluczowe: Elewacja wentylowana, Aprobata Techniczna, projekt, wykonanie i odbiór robót budowlano-montażowych.

\section{Wprowadzenie}

Elewacje wentylowane cieszą się coraz większą popularnością. Znajdują zastosowanie prawie we wszystkich typach nowych lub rekonstruowanych budynków, między innymi w: budynkach mieszkalnych, biurowych, budynkach infrastruktury komunikacyjnej (dworce, stacje benzynowe, porty lotnicze i morskie), budynkach przemysłowych. Niestety, widoczny jest również wzrost sporów sądowych związanych z jakością prac montażowych tego typu rozwiązań elewacyjnych. Przyczyny sporów są najczęściej związane z niewystarczającą wiedzą projektantów o elewacjach wentylowanych, a także kadry nadzorującej prace montażowe. W wielu przypadkach pozostawiają sporo do życzenia kompetencje montażystów. Sytuacja ta wynika z faktu, że tematyka elewacji wentylowanych nie jest ujęta dostatecznie szczegółowo w programach nauczania szkół wyższych, techników oraz szkół zawodowych.

Celem artykułu jest przedstawienie problemów wykonania i odbioru elewacji wentylowanych.

\section{Problemy wykonania elewacji wentylowanych}

Najczęściej spotykanym formalnym błędem związanym ze stosowaniem w budownictwie elewacji wentylowanych jest wbudowanie elewacji nieposiadającej (krajowej) Aprobaty Technicznej lub Europejskiej Oceny Technicznej. Elewacje takie składają się z nieprzebadanych wcześniej jako całość elementów składowych. Zakres badań koniecznych do oceny technicznej elewacji wentylowanej został opisany w ETAG 034 [1] oraz w [2]. Nieprzebadanie w całości zestawu wyrobów do wykonania elewacji wentylowanej stanowi potencjalne zagrożenie dla życia i zdrowia ludzi. Nieprawdziwe jest przekonanie, że przeprowadzenie obliczeń przy pomocy powszechnie stosowanych programów inżynierskich pozwoli na dokonanie adekwatnej oceny technicznej elewacji. Z doświadczenie eksperckiego ITB wynika, że niedoskonałości współczesnych narzędzi obliczeniowych nie pozwalają uwzględnić wszystkich czynników występujących podczas rzeczywistej eksploatacji elewacji. Postawioną tezę poniekąd potwierdza Ustawodawca - ETAG 034 nie przewiduje stosowanie metod obliczeniowych jako alternatywnych do badań laboratoryjnych. 
Nierzadko zdarzają się sytuacje, kiedy elewacje wbudowywane są na podstawie Aprobat Technicznych Państw Członkowskich. Wykorzystanie takich wyrobów wymaga głębokiej analizy zagranicznej Aprobaty Technicznej. Aprobaty te mogą nie mieć sprawdzonych istotnych z punktu widzenia warunków Polski właściwości, dotyczy to przede wszystkim Aprobat wydanych na Południu Europy. Może zabraknąć w nich badań klimatycznych, określających odporność elewacji na cykle wielokrotnego zamrażania - rozmrażania.

Kolejnym istotnym problemem występującym podczas wykonania elewacji wentylowanej jest brak lub niekompletność projektu. Zakres projektu elewacji wentylowanej pozwalający na wykonanie trwałej i bezpiecznej konstrukcji został omówiony w Warunkach Technicznych Wykonania i Odbioru Robót [3] oraz w [4]. Projekt powinien być zgodny z wytycznymi Aprobaty Technicznej. Dokumentacja Aprobująca jest podstawowym źródłem wiedzy projektanta $\mathrm{w}$ zakresie istotnych kwestii bezpieczeństwa użytkowania i trwałości, np.: doboru rozstawu rusztu oraz okładzin w różnych strefach elewacji budynku (np. w strefach bardziej i mniej narażonych na uderzenie, stref o innych wartościach obciążeniem wiatrem). Spora część błędów wykonawczych popełnianych w trakcie budowy ma związek z lukami i nieścisłościami dokumentacji projektowej. Projekt elewacji wentylowanej powinien składać się z trzech składowych: opisowej, obliczeniowej, graficznej. Brak jakiejkolwiek z tych części może spowodować liczne pomyłki wykonawcze, być przyczyną szybkiej degradacji elewacji. Np., brak części opisowej może doprowadzić do zastosowania elewacji wentylowanej o niskiej klasie odporności na działanie korozji w rejonach o dużej agresywności korozyjnej. Nierzadko brak części obliczeniowej prowadził do osuwania się okładzin elewacyjnych pod własną masą, ponieważ ruszt nie wytrzymywał występujących obciążeń lub zawaleniem się fragmentów elewacji na narożnikach górnej partii budynku. Brak części rysunkowej jest częstą przyczyną niewłaściwego montażu rusztu w częściach cokołowych, nadproża, na poziomie balkonów.

Ważnym elementem wykonania elewacji wentylowanych jest adekwatna ocena stanu technicznego ścian, do których będą one mocowane. Oprócz właściwości geometrycznych (odchyłka od pionu czy poziomu) ściana powinna spełniać wymagania projektu w zakresie nośności. Przymocowana do ściany konsola powinna bez uszkodzeń przenieść zakładane w projekcie obciążenia poziome (wynikające ze ssania wiatru) oraz pionowe (wynikające z masy okładzin). Niestety, częstym zjawiskiem jest mocowanie elewacji wentylowanych do ścian nie spełniających tych kryteriów (np. do ścian mających ubytki cegły, spękania, odpadające tynki). Ściany niespełniające wymagań (założeń projektowych, warunków technicznych) zgodnie z [4] powinny zostać naprawione.

Podczas mocowania rusztu elewacji wentylowanej do ścian należy zwrócić szczególną uwagę na technikę montażu. Powszechnym błędem wykonawczym jest umieszczenie łączników mechanicznych do mocowania rusztów w spoinach murowych (fot. 1), osłabia to nośność połączenia konsoli z podłożem.

Mocowanie rusztu do ścian może być poważnie osłabione wskutek wiercenia otworu pod łącznik mechaniczny wiertarką z odbojem ( np., w przypadku pustaków doprowadza to do ich uszkodzeń).

Sporo usterek podczas montażu elewacji wentylowanych są związane z nieodpowiednim składowaniem, przenoszeniem okładzin. Szczególnie wrażliwymi są kasetony metalowe oraz wielkoformatowe okładziny (np.. włókno-cementowe, HPL). Transportowanie i przenoszenie okładzin powinno być zgodne z wytycznymi producenta.

Szczególną uwagę należy zwracać na zgodność narzędzi do obróbki rusztów i okładzin z wymaganiami producenta elewacji wentylowanej. Nieodpowiednie narzędzia mogą być przyczyną nieodwracalnych uszkodzeń tych elementów. 


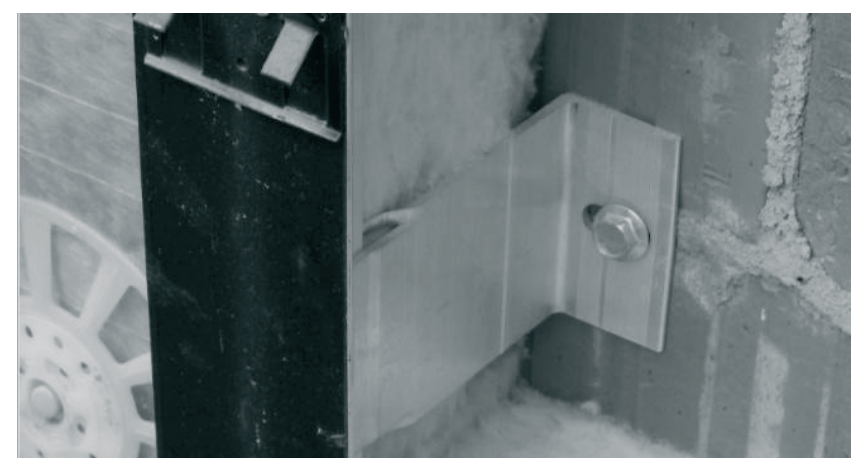

Fot. 1. Niepoprawne osadzenie kotew w spoinach podczas mocowania rusztu elewacyjnego do ścian

Podczas wykonania elewacji wentylowanej niedopuszczalnym jest zastosowanie elementów elewacji niewymienionych w dokumentacji aprobującej. Niebezpiecznym może być również wykorzystanie materiałów zamiennych nawet o podobnych parametrach wytrzymałościowych. Np. w przypadku aluminiowych elementów rusztu zamiana śrub samowiercących aluminiowych na stalowe (nie wymienionych w dokumentacji aprobującej) ocynkowane może doprowadzić do powstania ogniw korozyjnych.

Częstym błędem podczas montażu rusztu elewacyjnego są niedokładności związane z rozmieszczeniem konsoli. Pomyłka ta może uniemożliwić prawidłowy montaż okładzin, mieć negatywny wpływ na estetykę elewacji. Nierzadko dochodzi do niepoprawnego rozmieszczenia konsoli stałych i ruchomych co może doprowadzić do uszkodzenia konstrukcji elewacji wentylowanej. Niedopuszczalnym jest deformowanie elementów rusztu oraz zastosowanie uszkodzonych elementów. Przykład niepoprawnie wykonanego rusztu przedstawia fot. 2.

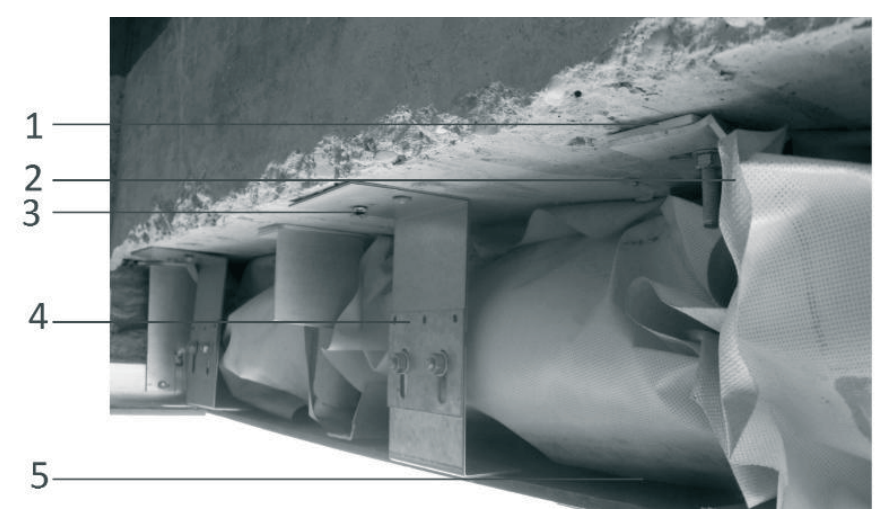

Fot. 2. Pomyłki przy wykonaniu elewacji wentylowanej: 1 - zastosowanie niesystemowych przekładek termicznych (wyrównujących?); 2 - zdeformowana konsola; 3 - niesystemowe łączniki mechaniczne; 4 - obrócona o 90o konsola; 5 - zapchana szczelina wentylacyjna.

Rozpowszechnioną pomyłką wykonawczą podczas układania docieplenia jest pozostawienie niewypełnionych materiałem termoizolacyjnym fragmentów ścian. W miejscach takich powstają mostki termiczne negatywnie wpływające na parametry izolacyjne przegrody. Kolejnym błędem (związanym z nieścisłościami projektu) jest zastosowanie wełny mineralnej w pasie przycokołowym (fot. 3) oraz na poziomie płyt balkonowych, gdyż zawilgocona wełna traci swoje właściwości termoizolacyjne. 
Podczas krycia wełny mineralnej folią paroprzepuszczalną niedopuszczalnym jest pozostawienie nieosłoniętych fragmentów termoizolacji (fot. 3). Folia powinna być rozprowadzona po powierzchni termoizolacji w sposób uniemożliwiający zatkanie szczeliny wentylacyjnej pomiędzy warstwą docieplenia a okładziną zewnętrzną.
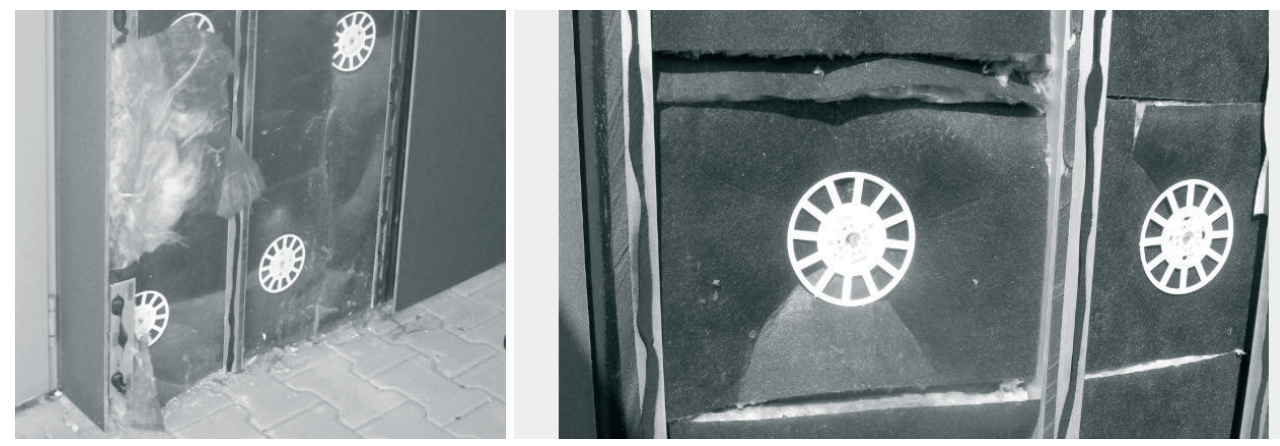

Fot. 3. Przykład niepoprawnie wykonanego docieplenia: wełna mineralna w pasie przycokołowym, odsłonięte fragmenty wełny, braki docieplenia na stykach płyt termoizolacyjnych

Częstym błędem wykonawczym jest rozmieszczenie łączników mechanicznych łączących okładzinę z rusztem bez odpowiedniego odstępu od krawędzi (fot. 4). Połączenie takie nie zapewnia odpowiedniej nośności i trwałości łączonego zestawu.

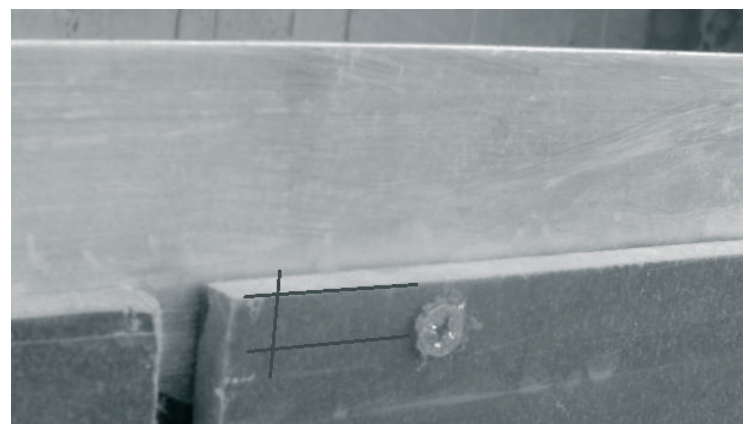

Fot. 4. Niewłaściwa odległość pomiędzy krawędzią okładziny włóknisto-cementową a otworem do łącznika mechanicznego (zamiast systemowych nitów zastosowano śrubę)

\section{Problemy odbioru elewacji wentylowanych}

Jakość wykonania robót elewacyjnych może być zapewniona wyłącznie w przypadku systematycznej pracy osób nadzorujących. Przed rozpoczęciem prac montażowych należy odebrać ściany, do których będzie mocowana elewacja wentylowana. Również powinien być zakończony i odebrany montaż stolarki okienno-drzwiowej. W trakcie montażu elewacji wentylowanej należy sprawdzać roboty zanikające na etapach: montażu rusztu, wykonania robót izolacyjnych, montażu okładzin.

Niedopuszczalnym jest zastosowanie i odbiór elewacji wentylowanej nie posiadającej (krajowej) Aprobaty Technicznej lub Europejskiej Oceny Technicznej.

W trakcie wykonywania robót elewacyjnych osoby nadzorujące powinny zwrócić szczególną uwagę na sposób transportowania, przechowywania oraz przenoszenia okładzin elewacyjnych. 
Niedopuszczalnym jest stosowanie sprzętu do docinania, obróbki elementów rusztu i okładzin sprzętu niezgodnego z wytycznymi producenta.

W przypadku elewacji wentylowanych z zastosowaniem połączeń klejowych należy zwracać szczególną uwagę na warunki przechowywania klejów oraz temperaturę i wilgotność powietrza podczas ich aplikacji i dojrzewania. Warunki termo-wilgotnościowe nie mogą przekraczać wskazanych w dokumentacji aprobującej. Podobną zasadę należy stosować podczas mocowania konsoli do ścian za pomocą kotew chemicznych.

Odbiór zamontowanego rusztu polega na sprawdzeniu odporności konsoli na odrywanie od powierzchni ścian (3 konsole na $100 \mathrm{~m}^{2}$ ściany). Uzyskany wynik nie może być niższy od podanego w dokumentacji projektowej / aprobującej. Sprawdza się również geometrię rozmieszczenia rusztu na ścianach. Szczególną uwagę należy poświęcić na sprawdzenie poprawności rozmieszczenia konsoli stałych i ruchomych. Również należy sprawdzić kształt, wymiary, rozstaw elementów rusztu na różnych fragmentach budynku (np. w strefach przycokołowych).

Podczas odbioru robót izolacyjnych należy sprawdzić:

- zgodność materiału i grubości termoizolacji z projektem na poszczególnych fragmentach budynku (np. niedopuszczalnym jest zastosowanie wełny mineralnej w pasie przycokołowym lub pasie balkonowym),

- prawidłowość docieplenia ram okiennych i drzwiowych,

- ciągłość termoizolacji i folii paroprzepuszczalnej.

Podczas montażu okładzin osoby nadzorujące powinny sprawdzać:

- czy przeprowadzono przedmontażową segregację okładzin w zakresie kolorystyki i użylenia;

- przyczepność okładzin do rusztu (w przypadku zastosowania klejenia);

- występowanie szczeliny pomiędzy okładziną a dociepleniem. Szczelina pomiędzy tymi elementami powinna wynosić co najmniej $20 \mathrm{~mm}$;

- płaskość oraz odchyłki okładzin od pionu i poziomu (nie powinny przekraczać wartości wskazanej w projekcie);

- prawidłowość przebiegu i kształtu spoin (powinny spełniać wymagania projektu);

- stan krawędzi okładzin (powinny być zgodne z wymaganiami dokumentacji aprobującej).

Szczegółowe procedury odbioru elewacji wentylowanych zostały przedstawione w [4].

\section{Podsumowanie}

Elewacje wentylowane nieposiadające krajowej lub europejskiej oceny technicznej nie gwarantują zapewnienia trwałej i bezpiecznej eksploatacji. Zawarte w tych dokumentach dane mają istotne znaczenie podczas projektowania elewacji.

Niebagatelny wpływ na trwałość, bezpieczeństwo oraz parametry eksploatacyjne elewacji wentylowanej ma jakość dokumentacji projektowej. Podstawowe elementy projektu elewacji wentylowanej zostały określone w [4].

Szczególną uwagę należy zwracać na stan techniczny ścian, do których będzie mocowana elewacja wentylowana. Ściany powinny spełniać wymagania projektu oraz dokumentacji aprobującej.

Sposób transportowania, przechowywania, technologia obróbki elementów składowych oraz montaż elewacji wentylowanej powinien być zgodny z wytycznymi producenta elewacji wentylowanej. Szczególna uwagę należy zwracać na stosowane podczas obróbki i montażu elewacji narzędzia. 
Podstawowy wpływ na jakość wykonania robót elewacyjnych ma doświadczenie i przygotowanie ekipy montażowej oraz osób nadzorujących te prace.

\section{Literatura}

1. EOTA ETAG 034 cz. 1 i 2. Zestawy do wykonywania oktadzin ścian zewnętrznych. Część 1: Zestawy okładzin wentylowanych wraz z elementami mocujacymi. Część 2: Zestawy zawierajace elementy okładzinowe, elementy mocujące, podkonstrukcję oraz wyroby izolacyjne.

2. Kopyłow O. Jaka powinna być elewacja wentylowana. Inżynier Budownictwa, nr 8/2012.

3. Kopyłow O. Co powinien zawierać projekt elewacji wentylowanej? Wiadomości Projektanta Budownictwa Nr 1/2014.

4. Kopyłow O. Elewacje wentylowane - Warunki Techniczne Wykonania i Odbioru Robót Budowlanych, Instytut Techniki Budowlanej B14/2015.

\section{Ventilated facades \\ - problems of execution and acceptance of works}

\section{Ołeksij Kopyłow}

Building Structures Department, Building Research Institute, e-mail: o.kopylov@itb.pl

Abstract: This article is written based on expert opinions provided by ITB. The paper presents the most common mistakes related with execution and acceptance of ventilated façade works. Discusses the errors resulting from the imperfections of design documentation, improper preparation of the performance and supervising staff.

Keywords: ventilated facade, ETA, design documentation, execution of works, acceptance testing procedure. 